\title{
Transforming growth factor- $\beta$ activation in cell-free extracellular matrix preparations. Commentary
}

\author{
John R. Couchman
}

Biotech Research \& Innovation Centre, University of Copenhagen, Denmark

\begin{abstract}
Transforming growth factor- $\beta$ (TGF- $\beta$ ) is an important regulator of many cellular and immunological functions. It is often deposited in extracellular matrices in a latent form. This commentary is to draw attention to the likelihood that preparing cell-free matrices from tissue cultures by high $\mathrm{pH}$ buffers, such as ammonium hydroxide, can activate the TGF- $\beta$. Therefore, cells subsequently seeded onto such matrices may respond to the presence of active TGF- $\beta$ in addition to interactions with macromolecular extracellular matrix components. (Folia Histochemica et Cytobiologica 2019, Vol. 57, No. 4, 157-158)
\end{abstract}

Key words: TGF- $\beta$; latent TGF-binding protein; cell free ECM; high $\mathrm{pH}$ buffers

As far back as the 1980s the roles of extracellular matrix (ECM) components in regulating cell behaviour became increasingly popular. In addition to reductionist work in isolating and carefully characterising individual matrix macromolecules, efforts were made to assess whole matrices. Gospodarowicz's group identified several methods to grow cell monolayers to confluency, allowing them to assemble extracellular matrices, then removing the cells to leave the matrix for analysis, or to seed other cells on them [1-3]. Among these techniques, low concentrations of detergent, such as Triton X-100 together with hypotonic solutions containing ammonium hydroxide were developed. This high $\mathrm{pH}$ method is effective, and little cell debris remains attached to the matrices that are left largely intact.

At that time, little was known about transforming growth factor- $\beta$ (TGF- $\beta$ ), but in the succeeding few years it became apparent that this important growth factor is expressed in a latent form. Activation of TGF- $\beta$ could be achieved in various ways, and early experiments with soluble, medium-derived growth factor showed that extremes of $\mathrm{pH}$ were highly effective

\footnotetext{
Correspondence address: John R. Couchman

Biotech Research \& Innovation Centre,

University of Copenhagen, Denmark

Biocentre 1.3.16, Ole Maaløes Vej 5,

2200 Copenhagen N, Denmark

e-mail: john.couchman@bric.ku.dk
}

[4-6]. Subsequently, a number of more physiologically relevant mechanisms to activate TGF- $\beta$ have been characterised, including proteases, thrombospondin-1, reactive oxygen species and several integrin receptors [5, 7-10].

Further developments in the field showed that latent TGF- $\beta$ could be inserted into the extracellular matrix through its interaction with large latent TGF-binding proteins (LTBPs), of which four distinct types are now known in mammals [11]. In this way the ECM serves as a reservoir of latent TGF- $\beta$ by virtue of its association with a structural matrix component, i.e. LTBP $[12,13]$.

What appears to have escaped widespread attention is that preparation of cell-free matrices from cell cultures through the use of ammonium hydroxide can activate matrix-associated TGF- $\beta$. Therefore, cells subsequently seeded onto matrices prepared in this way will encounter not only matrix components, interacting with integrins, syndecans, CD44 etc., but also activated TGF- $\beta$. Many years ago we found that matrices prepared from PF-HR9 mouse endodermal cells by alkali treatment would inhibit subsequently seeded mink lung epithelial cells (Mv1Lu) (M. Austria $\& \mathrm{~J}$. Couchman, unpublished results). It is well known that TGF- $\beta$ inhibits the proliferation of these cells [14], and in our case the inhibition could be overcome by TGF- $\beta$-specific blocking antibodies.

Even today current methods describe the use of $20 \mathrm{mM}$ ammonium hydroxide (sometimes in PBS with 
detergent $[15,16]$, or more usually in hypotonic conditions without detergent [17]), to prepare cell-free matrices, but there is no mention of the possibility that latent TGF- $\beta$ can be activated by this method. I have often encountered young scientists who use this method and many are surprised when I advise them that it can result in the activation of the matrix-associated TGF- $\beta$. Therefore, the purpose of this commentary is to bring this aspect of matrix biology to scientists' attention. Where this is a key issue, other methods at neutral $\mathrm{pH}$ can be used, such as $2 \mathrm{M}$ urea together with non-ionic detergents and hypotonic buffers $[3,17]$.

\section{References}

1. Gospodarowicz D, Ill C. The extracellular matrix and the control of proliferation of corneal endothelial and lens epithelial cells. Exp Eye Res. 1980; 31(2): 181-199, doi: 10.1016/00144835(80)90077-9, indexed in Pubmed: 7428843.

2. Gospodarowicz D, Hirabayashi K, Giguère L, et al. Factors controlling the proliferative rate, final cell density, and life span of bovine vascular smooth muscle cells in culture. J Cell Biol. 1981; 89(3): 568-578, doi: 10.1083/jcb.89.3.568, indexed in Pubmed: 6454694.

3. Gospodarowicz D, Gonzalez R, Fujii DK. Are factors originating from serum, plasma, or cultured cells involved in the growth-promoting effect of the extracellular matrix produced by cultured bovine corneal endothelial cells? J Cell Physiol. 1983; 114(2): 191-202, doi: 10.1002/jcp.1041140208, indexed in Pubmed: 6218176.

4. Lawrence DA, Pircher R, Jullien P. Conversion of a high molecular weight latent beta-TGF from chicken embryo fibroblasts into a low molecular weight active beta-TGF under acidic conditions. Biochem Biophys Res Commun. 1985; 133(3): 1026-1034, doi: 10.1016/0006-291x(85)91239-2, indexed in Pubmed: 3866579.

5. Lyons RM, Keski-Oja J, Moses HL. Proteolytic activation of latent transforming growth factor-beta from fibroblast-conditioned medium. J Cell Biol. 1988; 106(5): 1659-1665, doi: 10.1083/jcb.106.5.1659, indexed in Pubmed: 2967299.

6. Munger JS, Harpel JG, Gleizes PE, et al. Latent transforming growth factor-beta: structural features and mechanisms of activation. Kidney Int. 1997; 51(5): 1376-1382, doi: 10.1038/ ki.1997.188, indexed in Pubmed: 9150447.
7. Schultz-Cherry S, Murphy-Ullrich JE. Thrombospondin causes activation of latent transforming growth factor-beta secreted by endothelial cells by a novel mechanism. J Cell Biol. 1993; 122(4): 923-932, doi: 10.1083/jcb.122.4.923, indexed in Pubmed: 8349738.

8. Barcellos-Hoff MH, Dix TA. Redox-mediated activation of latent transforming growth factor-beta 1. Mol Endocrinol. 1996; 10(9): 1077-1083, doi: 10.1210/mend.10.9.8885242, indexed in Pubmed: 8885242.

9. Wipff PJ, Hinz B. Integrins and the activation of latent transforming growth factor beta1 - an intimate relationship. Eur J Cell Biol. 2008; 87(8-9): 601-615, doi: 10.1016/j. ejcb.2008.01.012, indexed in Pubmed: 18342983.

10. Hinz B. It has to be the $\alpha \mathrm{v}$ : myofibroblast integrins activate latent TGF- $\beta 1$. Nat Med. 2013; 19(12): 1567-1568, doi: 10.1038/ nm.3421, indexed in Pubmed: 24309651.

11. Rifkin DB, Rifkin WJ, Zilberberg L. LTBPs in biology and medicine: LTBP diseases. Matrix Biol. 2018; 71-72: 90-99, doi: 10.1016/j.matbio.2017.11.014, indexed in Pubmed: 29217273.

12. Taipale J, Miyazono K, Heldin CH, et al. Latent transforming growth factor-beta 1 associates to fibroblast extracellular matrix via latent TGF-beta binding protein. J Cell Biol. 1994; 124(1-2): 171-181, doi: 10.1083/jcb.124.1.171, indexed in Pubmed: 8294500.

13. Dallas SL, Miyazono K, Skerry TM, et al. Dual role for the latent transforming growth factor-beta binding protein in storage of latent TGF-beta in the extracellular matrix and as a structural matrix protein. J Cell Biol. 1995; 131(2): 539-549, doi: 10.1083/jcb.131.2.539, indexed in Pubmed: 7593177.

14. Cheifetz S, Weatherbee JA, Tsang ML, et al. The transforming growth factor-beta system, a complex pattern of cross-reactive ligands and receptors. Cell. 1987; 48(3): 409-415, doi: 10.1016/0092-8674(87)90192-9, indexed in Pubmed: 2879635.

15. Vlodavsky I. Preparation of extracellular matrices produced by cultured corneal endothelial and PF-HR9 endodermal cells. Curr Protoc Cell Biol. 2001; Chapter 10: Unit 10.4, doi: 10.1002/0471143030.cb1004s01, indexed in Pubmed: 18228298.

16. Franco-Barraza J, Beacham DA, Amatangelo MD, et al. Preparation of extracellular matrices produced by cultured and primary fibroblasts. Curr Protoc Cell Biol. 2016; 71: 10.9.1-10.9.34, doi: 10.1002/cpcb.2, indexed in Pubmed: 27245425.

17. Hellewell AL, Rosini S, Adams JC. A Rapid, Scalable method for the isolation, functional study, and analysis of cell-derived extracellular matrix. J Vis Exp. 2017(119), doi: 10.3791/55051, indexed in Pubmed: 28117783.

Submitted: 28 October, 2019

Accepted after reviews: 28 October, 2019 Available as AoP: 19 November, 2019 